\title{
Specialty Career Choices of Interns and Dental Students in the Clinical Years at Taif University
}

\author{
Amal A Ashour
}

\begin{abstract}
Aim and objective: The aim and objective of this study was to investigate the factors that influence the choice of specialty and career preferences in dental students and interns in their clinical years.

Materials and methods: This cross-sectional study was performed in the 5th-year and 6th-year dental students and interns at Taif University in Saudi Arabia. A self-administered questionnaire was formulated and sent electronically to the students via faculty e-mail. The responses were recorded on a Google spreadsheet, and the data were analyzed using SPSS for Windows.

Results: The majority of dental students expressed a preference for pediatric dentistry and restorative and esthetic dentistry. The main factor influencing their choice was the local shortage of dentists in these specialties. Negative experiences of students, their peers, or faculty members also affected the students' career choices.

Conclusion: This study provides baseline data for establishing plans to improve graduate programs in Saudi Arabia. Mentoring initiatives are needed to provide guidance and encouragement for undergraduate dental students when selecting the most appropriate future specialty.

Clinical significance: The choice of dental specialty is a challenge for dental students and is affected by many factors. The knowledge of the factors that influence their choice of specialty would help when addressing the requirements of job market.

Keywords: Career, Dental students, Influencing factors, Specialty.

World Journal of Dentistry (2020): 10.5005/jp-journals-10015-1748
\end{abstract}

\section{INTRODUCTION}

According to a 2017 Ministry of Education report, approximately 1400 dental students graduate annually from the 28 dental schools in Saudi Arabia. ${ }^{1}$ After graduation, students pursue careers and postgraduate studies that meet their personal needs from the available options. Typically, they start work at academic institutions or hospital dental units in order to hone their skills and gain further knowledge in a specialist area in dentistry. ${ }^{2}$ These early career choices lead to opportunities to gain formal specialist qualifications from the Saudi Health Commission. The Saudi Health Commission offers 10 dental specialty programs, including family dental medicine, restorative dentistry, pedodontics, oral pathology, implantology, periodontology, orthodontics, oral surgery, endodontics, and prosthodontics. ${ }^{3}$ Furthermore, several universities in Saudi Arabia offer postgraduate specialty programs that are recognized by the Saudi Health Commission. The knowledge of the factors that influence a graduate's choice of dental career would help when planning the dental workforce agenda. ${ }^{4}$

Many studies in general medicine and surgery have identified early career guidance and the support of inspiring clinicians as a key factor in career choices made by medical students and interns. The rotation system exposes students and interns to a broader range of specialties, which helps in the choice of a career. ${ }^{5}$ All medical organizations should offer career counseling for students and prepare them for potential difficulties that they may encounter after graduation. ${ }^{6,7}$

There is limited information on the factors that influence the choice of a career in dentistry and preferred specialty in Saudi Arabia. ${ }^{8}$ A study by Halawany in 2014 identified the preferred specialty to be maxillofacial surgery in $20.1 \%$ of male students and operative dentistry in $23.4 \%$ of female students. ${ }^{9}$ Another study
Department of Oral and Maxillofacial Surgery and Diagnostic Sciences, Faculty of Dentistry, Taif University, Taif, Kingdom of Saudi Arabia

Corresponding Author: Amal A Ashour, Department of Oral and Maxillofacial Surgery and Diagnostic Sciences, Faculty of Dentistry, Taif University, Taif, Kingdom of Saudi Arabia, Phone: +966556565573, e-mail: a.a.ashour@tudent.edu.sa

How to cite this article: Ashour AA. Specialty Career Choices of Interns and Dental Students in the Clinical Years at Taif University. World J Dent 2020;11(4):265-273.

Source of support: Nil

Conflict of interest: None

in 2017 found that $17.7 \%$ of dental students surveyed expressed a preference for a career in restorative and esthetic dentistry while $14.1 \%$ preferred endodontics, $11.7 \%$ chose prosthodontics, and $11.4 \%$ opted for orthodontics. ${ }^{4}$ The same study also found "influence of family members in the dental profession" to be the most important determinant of career choice.

The important factors influencing the choice of dentistry as a profession include general interest, ${ }^{10,11}$ the artistic component of dentistry, ${ }_{1}^{12-15}$ social standing and professional status, ${ }_{1}^{16}$ the ability to be self-employed, ${ }^{12,15}$ opportunity to help people, ${ }^{10,12,15,17}$ and good income. ${ }^{12,15,16}$ Thereafter, population demographics may influence the choice of specialty in dental graduates. ${ }^{11,18-22}$ In Saudi Arabia, the strongest determinants of a graduate's choice of dental specialty are having family members in the dental profession, preference for private practice, and an interest in treating a specific patient population. ${ }^{4}$ Interest in a specific patient population was found to be the most important factor influencing the choice of restorative and esthetic dentistry as a future specialty by Saudi dental graduates. ${ }^{4}$ 
The above-mentioned research on career choice by Saudi dental graduates and their preferred specialties has been conducted at a nationwide level. ${ }^{4,9}$ Such information is also required at the regional level so that providers of specialty programs at the various universities and the Saudi Health Commission can balance their curricula with community needs. The aim of this study was to identify factors influencing the choice of career and specialty in dental students and interns at Taif University.

\section{Materials and Methods}

The study had a cross-sectional design and included 5th-year and 6th-year dental students and interns at Taif University, Taif, Saudi Arabia, during the period from February to April 2019. The study protocol was approved by the research and ethics committee at Taif University (clearance number 41-7027-0027). After reviewing the relevant literature, a questionnaire was developed to obtain the demographic data (date of birth, year of study, grade point average, information on whether or not the respondent had a first-degree relative in the medical or dental field), information on preferred specialty and its determinants, the reasons why some specialties were not considered, and preference for completing postgraduate education abroad or locally. ${ }^{4,79}$ The questionnaire was converted into an electronic version using Google forms and emailed to the study population. The responses were recorded in a Google spreadsheet. The data collected were anonymized, which ensured respondent confidentiality during the survey.

\section{Statistical Analysis}

Frequency distribution tables were constructed for all independent and outcome variables. Proportions were examined for differences using the Chi-square test and Kruskal-Wallis $\mathrm{H}$ analysis of variance followed by intergroup comparison using the Mann-Whitney $U$ test. All statistical analyzes were performed using SPSS for Windows version 17 (IBM Corp., Armonk, NY, USA). All statistical tests were two-sided and a $p$ value $<0.05$ was considered statistically significant.

\section{Results}

Fifty-two of the 56 students at Taif University at the time of the survey completed and returned the questionnaire. Seventeen respondents were 5th-year students, 21 were 6 th-year students, and 14 were interns. Most of the study participants had a grade point average of $<3.5$ (Table 1) and approximately half had a first-degree relative in the medical or dental field (Table 2 ).

Sixth-year students were significantly more likely to select pediatric dentistry as a career than 5th-year students $(p=0.03)$, whereas dental interns were more likely to select restorative and esthetic dentistry (Table 3 ). The main reason for the career choice given by 5 th-year students was personal interest. In the 6th-year, the reasons were future job opportunities, diversity of cases, high earning potential, opportunity to generate income in private practice, and shortage of specialists (Table 4). Students in their internship cited reasons of personal interest, shortage of specialists, and a positive experience during their undergraduate elective rotation.

Most of the students in their 5th and 6th years reported that they would not choose oral and maxillofacial surgery as a specialty career (Table 5), citing poor quality of life, lack of direct contact with patients, no opportunity for private practice, poor patient outcomes, and high clinical workload (Table 6). Most dental interns reported that they would not choose pediatric dentistry because of difficulties in managing behavior in children. In contrast, 5th-year students preferred pediatric dentistry and restorative dentistry, whereas 6th-year students preferred endodontics and orthodontics and interns preferred oral and maxillofacial surgery (Table 7). The proportion of 6th-year students who preferred orthodontics was significantly greater than that of 5th-year students and interns $(p=0.03)$.

Most of the study participants were planning to continue their postgraduate studies abroad (Table 8); the reasons given being better learning opportunities, newly established local programs, new specialty opportunities, experiencing another culture, and better research opportunities (Table 9).

\section{Discussion}

This study investigated the factors influencing career choices and specialty preferences in students in their 5th and 6th years of training and in dental interns at Taif University. The survey response rate of $93 \%$ was considered satisfactory.

Selection of specialty careers by dental students has been studied in several countries, including Saudi Arabia., 4,-13,15 The findings of these studies have helped education providers to tailor specialty programs to the preferences of graduates, many of whom have an interest in postgraduate dental education. The various postgraduate dental programs differ in content but all have a focus on ongoing improvement in the quality of care, research, extending dental care to as many Saudi Arabians as possible, and increasing the number of qualified specialists in the country. ${ }^{23}$

An important finding in this study was that $50 \%$ of Taif Dental College students had a first-degree relative in the medical or dental field. This is consistent with a recent report by Halawany et al., who cited "influence of family members in the dental profession" as the strongest determinant of choice of dental specialty. ${ }^{4}$ Dental students and interns in the present study chose their future specialty according to personal interest, future job opportunities, diversity of cases, high earning potential, opportunity to generate income in private practice, shortage of specialists in particular areas,

Table 1: Distribution of study participants according to their grade point average

\begin{tabular}{llcccc}
\hline & & Year 5 & Year 6 & Intern & Total \\
\hline What is your mean GPA? & $<3.5$ & 12 & 15 & 9 & 36 \\
& $>4.5$ & 0 & 4 & 2 & 3 \\
& $4.49-3.5$ & 5 & 2 & 14 & 10 \\
Total & & 17 & 21 & 0.09 & 0.09 \\
Kruskal-Wallis H & & 0.07 & & 0.09 \\
\hline
\end{tabular}

GPA, grade point average 
Career Plans of Taif Interns and Dental Students

Table 2: Distribution of study participants according to whether they had a first-degree relative in the medical or dental field

\begin{tabular}{lcccccc}
\hline & & Year 5 & Year 6 & Intern & Total & Kruskal-Wallis H \\
\hline Do you have a first-degree relative in & No & 8 & 11 & 7 & 26 & 0.07 \\
medicine or dentistry? & Yes & 9 & 10 & 7 & 26 & 0.08 \\
Total & & 17 & 21 & 14 & 52 & \\
Chi-square & & 0.07 & 0.09 & 0.09 & & \\
\hline
\end{tabular}

Table 3: Distribution of study participants according to their career choice

\begin{tabular}{|c|c|c|c|c|c|c|}
\hline & & Year 5 & Year 6 & Intern & Total & Kruskal-Wallis $\mathrm{H}$ \\
\hline \multirow{10}{*}{$\begin{array}{l}\text { Which of the following } \\
\text { specialties would you } \\
\text { choose as a career? }\end{array}$} & Pediatric dentistry & 2 & 8 & 0 & 10 & 0.03 \\
\hline & Restorative and esthetic dentistry & 4 & 7 & 5 & 16 & 0.08 \\
\hline & Endodontics & 0 & 2 & 2 & 4 & 0.09 \\
\hline & Oral and maxillofacial pathology & 1 & 0 & 2 & 3 & 0.07 \\
\hline & Oral medicine & 2 & 0 & 1 & 3 & NA \\
\hline & Dental surgery & 3 & 0 & 0 & 3 & NA \\
\hline & Oral and maxillofacial surgery & 2 & 0 & 0 & 2 & 0.07 \\
\hline & Orthodontics & 1 & 3 & 1 & 5 & NA \\
\hline & Prosthodontics & 0 & 0 & 2 & 2 & NA \\
\hline & Have not decided & 2 & 1 & 1 & 4 & NA \\
\hline Total & & 17 & 21 & 14 & 52 & \\
\hline
\end{tabular}

NA, not applicable

and a positive experience during undergraduate elective rotation. These factors should be considered in initial career guidance, support provided in the undergraduate and internship years, and during elective rotations. ${ }^{5-7}$

In this study, pediatric dentistry was the specialty preferred by only 5 th-year and 6 th-year respondents, whereas restorative and esthetic dentistry was the specialty preferred by 5th-year respondents, 6th-year respondents, and interns. This finding is in contrast with that of Sam et al., who found that dental students at the Prince Sattam Bin Abdulaziz University preferred orthodontics, oral and maxillofacial surgery, and prosthodontics and implantology. ${ }^{23}$ Similarly, Halawany et al. reported that Saudi Arabian dental students in their final year preferred restorative and esthetic dentistry as a future specialty. ${ }^{4}$ Factors affecting students' career choices were based not only on personal interest but also on the local shortage of specialists in particular areas, which is an important consideration in efforts to increase the specialist-topatient ratio in Saudi Arabia. ${ }^{23}$ Other determinants of career choice identified in the present study, such as high earning potential and a positive experience during undergraduate elective rotations, were similar to those in other reports. ${ }^{5-7,24}$

Most 5th-year and 6th-year students in this study excluded oral and maxillofacial surgery as a career choice, citing reasons of poor quality of life, lack of direct patient contact, no opportunity for private practice, poor patient outcomes, and high clinical commitments and workload. In contrast, most dental interns excluded pediatric dentistry because of the difficulties inherent in managing the behavior of children.

On balance, the findings of this study highlight the profound impact of negative experiences of dental students and interns on career choice and are consistent with earlier reports. ${ }^{4,7,24}$ A systematic review published in 2013 concluded that the problem of dental caries in Saudi children needs to be addressed at a government level and by dentists in all sectors. ${ }^{25}$ The finding in the present study that interns showed little interest in pediatric dentistry should prompt postgraduate programs to encourage undergraduates to pursue specialization in pediatric dentistry.

The 5th-year and 6th-year students in this study expressed a preference for pediatric dentistry, restorative dentistry, endodontics, and orthodontics whereas dental interns preferred oral and maxillofacial surgery. The most likely reason for this change in career choice is exposure to different specialty areas during the clinical years of training. ${ }^{7}$ A similar pattern of change in the choice of future dental specialty with increasing clinical experience was mentioned in the report by Abdulghani et al. ${ }^{26}$

The present finding that most students preferred to pursue postgraduate studies abroad echoes that of the study performed in 2010 by Al-Dlaigan et al. ${ }^{27}$ Reasons given for wanting to study abroad were better learning opportunities, more recently updated programs, new specialties, experiencing another culture, and better research opportunities. These results highlight the need for a plan to improve local postgraduate programs in order to attract graduate students as well as to direct students to postgraduate dental education. Besides, it is advisable to the dental graduates to choose the specialty according to the national statistics which presents specialty shortage, such as, pediatric dentistry. ${ }^{25}$

A potential limitation of this study is that data were only collected from 5th-year and 6th-year dental students and interns at Taif University and, thus, represents only a small sample of the population. Further research that involves a larger sample size may provide additional insight.

In conclusion, the findings of this study indicate that dental students presently at Taif University would prefer to specialize in pediatric dentistry and restorative and esthetic dentistry. The strongest determinants of their career decisions are the local 
Table 4: Distribution of study participants according to factors influencing career choice

\begin{tabular}{|c|c|c|c|c|c|c|}
\hline & & Year 5 & Year 6 & Intern & Total & Kruskal-Wallis $\mathrm{H}$ \\
\hline \multirow{26}{*}{$\begin{array}{l}\text { What factors have } \\
\text { influenced your } \\
\text { choice? }\end{array}$} & Family expectations & 0 & 1 & 0 & 1 & NA \\
\hline & Family expectations, high income potential & 0 & 1 & 0 & 1 & NA \\
\hline & $\begin{array}{l}\text { Family expectations, teacher or preceptor's advice and } \\
\text { recommendation, advice of a friend, prestige of the } \\
\text { specialty, research opportunities, location of practice, } \\
\text { high earning potential }\end{array}$ & 0 & 1 & 0 & 1 & NA \\
\hline & $\begin{array}{l}\text { Future job opportunities, diversity of cases, high earning } \\
\text { potential, income generated in private practice }\end{array}$ & 0 & 2 & 0 & 2 & NA \\
\hline & Income generated in private practice & 0 & 2 & 0 & 2 & NA \\
\hline & $\begin{array}{l}\text { Income generated in private practice, future job } \\
\text { opportunities }\end{array}$ & 0 & 0 & 1 & 1 & NA \\
\hline & $\begin{array}{l}\text { Income generated in private practice, future job } \\
\text { opportunities }\end{array}$ & 0 & 2 & 0 & 2 & NA \\
\hline & $\begin{array}{l}\text { Income generated in private practice, high earning } \\
\text { potential }\end{array}$ & 0 & 0 & 1 & 1 & NA \\
\hline & $\begin{array}{l}\text { Income generated in private practice, shortage of } \\
\text { specialists }\end{array}$ & 0 & 2 & 0 & 2 & NA \\
\hline & Personal interest & 2 & 0 & 0 & 2 & NA \\
\hline & Personal interest, high earning potential & 1 & 0 & 2 & 3 & NA \\
\hline & $\begin{array}{l}\text { Personal interest, a positive experience during } \\
\text { undergraduate elective rotation, high earning potential }\end{array}$ & 0 & 1 & 0 & 1 & NA \\
\hline & $\begin{array}{l}\text { Personal interest, a positive experience during } \\
\text { undergraduate elective rotation, future job } \\
\text { opportunities }\end{array}$ & 0 & 1 & 0 & 1 & NA \\
\hline & Personal interest, future job opportunities & 1 & 0 & 0 & 1 & NA \\
\hline & $\begin{array}{l}\text { Personal interest, future job opportunities, less risk of } \\
\text { patient morbidity and mortality, high income potential }\end{array}$ & 0 & 0 & 1 & 1 & NA \\
\hline & $\begin{array}{l}\text { Personal interest, future job opportunities, more oppor- } \\
\text { tunity to serve people and the community }\end{array}$ & 0 & 0 & 1 & 1 & NA \\
\hline & $\begin{array}{l}\text { Personal interest, future job opportunities, option to } \\
\text { practice abroad, high earning potential }\end{array}$ & 0 & 1 & 0 & 1 & NA \\
\hline & $\begin{array}{l}\text { Personal interest, future job opportunities, option to } \\
\text { practice abroad, high earning potential, shortage of } \\
\text { specialists }\end{array}$ & 0 & 1 & 0 & 1 & NA \\
\hline & $\begin{array}{l}\text { Personal interest, future job opportunities, research } \\
\text { opportunities, more opportunity to serve people and } \\
\text { the community }\end{array}$ & 0 & 0 & 1 & 1 & NA \\
\hline & $\begin{array}{l}\text { Personal interest, high earning potential, shortage of } \\
\text { specialists, more opportunity to serve people and the } \\
\text { community }\end{array}$ & 1 & 0 & 0 & 1 & NA \\
\hline & $\begin{array}{l}\text { Personal interest, less risk of patient morbidity } \\
\text { and mortality, high earning potential, future job } \\
\text { opportunities, income generated in private practice }\end{array}$ & 0 & 1 & 0 & 1 & NA \\
\hline & $\begin{array}{l}\text { Personal interest, less risk of patient morbidity and } \\
\text { mortality, high earning potential, income generated in } \\
\text { private practice }\end{array}$ & 0 & 1 & 0 & 1 & NA \\
\hline & $\begin{array}{l}\text { Personal interest, more opportunity to serve people and } \\
\text { the community }\end{array}$ & 1 & 0 & 0 & 1 & NA \\
\hline & $\begin{array}{l}\text { Personal interest, prestige of the specialty, future job } \\
\text { opportunities }\end{array}$ & 0 & 0 & 1 & 1 & NA \\
\hline & $\begin{array}{l}\text { Personal interest, prestige of the specialty, future job } \\
\text { opportunities, perceived ability (inclination), less risk of } \\
\text { patient morbidity and mortality, high income potential }\end{array}$ & 1 & 0 & 0 & 1 & NA \\
\hline & $\begin{array}{l}\text { Personal interest, prestige of the specialty, less risk of } \\
\text { patient morbidity and mortality, high earning potential, } \\
\text { income generated in private practice }\end{array}$ & 0 & 1 & 0 & 1 & NA \\
\hline
\end{tabular}


Contd...

\begin{tabular}{|c|c|c|c|c|c|c|}
\hline & & Year 5 & Year 6 & Intern & Total & Kruskal-Wallis H \\
\hline & $\begin{array}{l}\text { Personal interest, prestige of the specialty, perceived } \\
\text { ability (inclination), less risk of patient morbidity and } \\
\text { mortality, high earning potential }\end{array}$ & 1 & 0 & 0 & 1 & NA \\
\hline & $\begin{array}{l}\text { Personal interest, prestige of the specialty, research } \\
\text { opportunities, more opportunity to serve people and } \\
\text { the community, high earning potential }\end{array}$ & 1 & 0 & 0 & 1 & NA \\
\hline & $\begin{array}{l}\text { Personal interest, prestige of the specialty, research } \\
\text { opportunities, more opportunities to serve people and } \\
\text { the community, shortage of specialists }\end{array}$ & 1 & 0 & 0 & 1 & NA \\
\hline & $\begin{array}{l}\text { Personal interest, research opportunities, more } \\
\text { opportunity to serve people and the community }\end{array}$ & 1 & 0 & 0 & 1 & NA \\
\hline & Personal interest, shortage of specialists & 0 & 0 & 1 & 1 & NA \\
\hline & $\begin{array}{l}\text { Personal interest, shortage of specialists, a positive } \\
\text { experience during undergraduate elective rotation }\end{array}$ & 0 & 2 & 1 & 3 & NA \\
\hline & $\begin{array}{l}\text { Personal interest, teacher's or preceptor's advice and } \\
\text { recommendation, future job opportunities }\end{array}$ & 0 & 0 & 1 & 1 & NA \\
\hline & $\begin{array}{l}\text { Personal interest, teacher's or preceptor's advice and } \\
\text { recommendation, future job opportunities, option to } \\
\text { practice abroad, more opportunity to serve people and } \\
\text { the community }\end{array}$ & 1 & 0 & 0 & 1 & NA \\
\hline & $\begin{array}{l}\text { Personal interest, teacher's or preceptor's advice } \\
\text { and recommendation, future job opportunities, } \\
\text { prestige of the specialty, diversity of cases, option } \\
\text { to practice abroad, a positive experience during } \\
\text { undergraduate elective rotation, more opportunity to } \\
\text { serve people and the community, less risk of patient } \\
\text { morbidity and mortality, high earning potential, income } \\
\text { generated in private practice }\end{array}$ & 0 & 0 & 1 & 1 & NA \\
\hline & $\begin{array}{l}\text { Personal interest, teacher's or preceptor's advice and } \\
\text { recommendation, future job opportunities, shortage of } \\
\text { specialists }\end{array}$ & 1 & 0 & 0 & 1 & NA \\
\hline & $\begin{array}{l}\text { Personal interest, teacher's or preceptor's advice and } \\
\text { recommendation, option to practice abroad, more } \\
\text { opportunity to serve people and the community, high } \\
\text { earning potential }\end{array}$ & 1 & 0 & 0 & 1 & NA \\
\hline & $\begin{array}{l}\text { Personal interest, teacher's or preceptor's advice and } \\
\text { recommendation, prestige of the specialty, diversity of } \\
\text { cases, option to practice abroad, a positive experience } \\
\text { during undergraduate elective rotation, more } \\
\text { opportunity to serve people and the community, less } \\
\text { risk of patient morbidity and mortality, high earning } \\
\text { potential, income generated in private practice }\end{array}$ & 0 & 0 & 1 & 1 & NA \\
\hline & $\begin{array}{l}\text { Personal interest, teaching opportunities in other medi- } \\
\text { cal colleges, research opportunities, more opportunity } \\
\text { to serve people and the community }\end{array}$ & 0 & 0 & 1 & 1 & NA \\
\hline & $\begin{array}{l}\text { Personal interest, teaching opportunities in other medi- } \\
\text { cal college, research opportunities, more opportunity to } \\
\text { serve people and the community }\end{array}$ & 1 & 0 & 0 & 1 & NA \\
\hline & Teacher or preceptor's advice and recommendation & 1 & 0 & 0 & 1 & NA \\
\hline & $\begin{array}{l}\text { Teacher or preceptor's advice and recommendation, } \\
\text { friend's advice, prestige of the specialty, research } \\
\text { opportunities, location of practice, high earning } \\
\text { potential }\end{array}$ & 0 & 1 & 0 & 1 & NA \\
\hline & $\begin{array}{l}\text { Teacher's or preceptor's advice and recommendation, } \\
\text { future job opportunities }\end{array}$ & 1 & 0 & 0 & 1 & NA \\
\hline Total & & 17 & 21 & 14 & 52 & \\
\hline
\end{tabular}

NA, not applicable 
Table 5: Distribution of study participants according to the specialty they would not choose

\begin{tabular}{|c|c|c|c|c|c|c|}
\hline & \multirow{2}{*}{ Pediatric dentistry } & \multirow{2}{*}{$\frac{\text { Year } 5}{4}$} & \multirow{2}{*}{$\begin{array}{l}\text { Year } 6 \\
0\end{array}$} & \multirow{2}{*}{$\frac{\text { Intern }}{8}$} & \multirow{2}{*}{$\begin{array}{l}\text { Total } \\
12\end{array}$} & \multirow{2}{*}{$\begin{array}{l}\text { Kruskal-Wallis } H \\
0.03\end{array}$} \\
\hline \multirow{9}{*}{$\begin{array}{l}\text { What is the specialty } \\
\text { that you would not } \\
\text { select? }\end{array}$} & & & & & & \\
\hline & Community dentistry & 0 & 2 & 0 & 2 & NA \\
\hline & Oral biomaterial & 2 & 0 & 0 & 2 & NA \\
\hline & Endodontics & 0 & 6 & 0 & 6 & NA \\
\hline & Oral and maxillofacial pathology & 3 & 1 & 1 & 5 & NA \\
\hline & Oral medicine & 0 & 2 & 0 & 2 & NA \\
\hline & Oral and maxillofacial surgery & 6 & 8 & 4 & 18 & 0.04 \\
\hline & Prosthodontics & 1 & 2 & 0 & 3 & NA \\
\hline & Have not decided & 1 & 0 & 1 & 2 & NA \\
\hline Total & & 17 & 21 & 14 & 52 & \\
\hline
\end{tabular}

Table 6: Distribution of study participants according to reasons for exclusion of some careers

\begin{tabular}{|c|c|c|c|c|c|}
\hline & & Year 5 & Year 6 & Intern & Total \\
\hline \multirow{30}{*}{$\begin{array}{l}\text { What factors made } \\
\text { you exclude it? }\end{array}$} & Behavior & 1 & 0 & 2 & 3 \\
\hline & Chronic diseases & 0 & 4 & 0 & 4 \\
\hline & Chronic diseases, exclusively hospital-based career & 0 & 1 & 0 & 1 \\
\hline & $\begin{array}{l}\text { Chronic diseases, poor quality of life, exclusively hospital-based } \\
\text { career }\end{array}$ & 0 & 1 & 0 & 1 \\
\hline & Excess clinical activity, workload & 0 & 3 & 0 & 3 \\
\hline & Excess clinical activity, workload, poor quality of life & 1 & 1 & 1 & 3 \\
\hline & Exclusively hospital-based career, excess clinical activity, workload & 0 & 2 & 0 & 2 \\
\hline & $\begin{array}{l}\text { Exclusively hospital-based career, no technical workload, chronic } \\
\text { diseases }\end{array}$ & 0 & 1 & 0 & 1 \\
\hline & $\begin{array}{l}\text { Exclusively hospital-based career, no technical workload, chronic } \\
\text { diseases, poor quality of life }\end{array}$ & 0 & 1 & 0 & 1 \\
\hline & I do not like children & 0 & 0 & 1 & 1 \\
\hline & I do not like dealing with children's behavior & 0 & 0 & 1 & 1 \\
\hline & I do not like dealing with children's behavior & 0 & 0 & 1 & 1 \\
\hline & I do not like it & 0 & 0 & 1 & 1 \\
\hline & I do not like it, poor quality of life & 0 & 0 & 1 & 1 \\
\hline & Judicial proceedings & 1 & 0 & 0 & 1 \\
\hline & Judicial proceedings, excess clinical workload & 0 & 1 & 0 & 1 \\
\hline & Judicial proceedings, exclusively hospital-based career & 1 & 0 & 0 & 1 \\
\hline & Judicial proceedings, poor quality of life & 1 & 0 & 0 & 1 \\
\hline & Lack of recognition & 0 & 2 & 0 & 2 \\
\hline & No patient contact, behavior & 0 & 0 & 1 & 1 \\
\hline & No patient contact, exclusively hospital-based career & 1 & 0 & 0 & 1 \\
\hline & No patient contact, lack of recognition & 1 & 0 & 0 & 1 \\
\hline & No patient contact, lack of recognition & 1 & 0 & 0 & 1 \\
\hline & No patient contact, no private practice & 1 & 0 & 0 & 1 \\
\hline & No patient contact, poor quality of life & 1 & 0 & 0 & 1 \\
\hline & No private practice & 0 & 2 & 0 & 2 \\
\hline & $\begin{array}{l}\text { No technical workload, occupational hazards, e.g., radiation, drug- } \\
\text { addicted patients, workload }\end{array}$ & 0 & 2 & 0 & 2 \\
\hline & Nothing & 1 & 0 & 0 & 1 \\
\hline & Poor quality of life & 1 & 0 & 0 & 1 \\
\hline & Poor quality of life, exclusively hospital-based career & 1 & 0 & 0 & 1 \\
\hline
\end{tabular}


Contd...

NA, not applicable

Poor quality of life, exclusively hospital-based career, no patient Year 5 contact, occupational hazards, e.g., radiation, drug-addicted patients, lack of recognition, chronic diseases, judicial proceedings, competition, poor patient outcomes, excess of clinical activities, workload Poor quality of life, exclusively hospital-based career, no patient contact, no technical workload, no private practice, occupational hazards, e.g., radiation and drug-addicted patients, lack of recognition, chronic diseases, judicial proceedings, competition, poor patient outcomes, excess clinical activity, workload

Poor quality of life, exclusively hospital-based career, no private practice

Poor quality of life, no patient contact, no technical workload, no private practice

Poor quality of life, no patient contact, poor patient outcomes, excess clinical activity, workload

Poor quality of life, no private practice

0

\begin{tabular}{cccc} 
Year 6 & Intern & Total \\
\hline 0 & 1 & 1
\end{tabular}

0

0

1

1

Poor quality of life, no privatepractice

\begin{tabular}{cccc}
0 & 0 & 1 & 1 \\
2 & 0 & 0 & 2 \\
2 & 0 & 0 & 2 \\
0 & 0 & 2 & 2 \\
17 & 21 & 14 & 52 \\
\hline
\end{tabular}

Table 7: Distribution of study participants according to preferred specialty during the basic science year

\begin{tabular}{|c|c|c|c|c|c|c|}
\hline $\begin{array}{l}\text { What was your } \\
\text { preferred specialty } \\
\text { during the basic sci- } \\
\text { ence year? }\end{array}$ & & Year 5 & Year 6 & Intern & Total & Kruskal-Wallis H \\
\hline \multirow{11}{*}{$\begin{array}{l}\text { What was your } \\
\text { preferred specialty } \\
\text { during the basic sci- } \\
\text { ence year? }\end{array}$} & Pediatric dentistry & 3 & 0 & 1 & 4 & NA \\
\hline & Restorative dentistry & 3 & 2 & 0 & 5 & 0.09 \\
\hline & Endodontics & 0 & 6 & 0 & 6 & NA \\
\hline & Cosmetic dentistry & 0 & 3 & 1 & 4 & NA \\
\hline & Oral and maxillofacial pathology & 2 & 0 & 3 & 5 & 0.09 \\
\hline & Oral medicine & 2 & 0 & 0 & 2 & NA \\
\hline & Oral and maxillofacial surgery & 2 & 0 & 2 & 4 & 0.09 \\
\hline & Orthodontics & 1 & 8 & 2 & 11 & 0.03 \\
\hline & Prosthodontics & 0 & 2 & 2 & 4 & 0.09 \\
\hline & Oral and maxillofacial radiology & 2 & 0 & 0 & 2 & NA \\
\hline & Have not decided & 2 & 0 & 3 & 5 & 0.09 \\
\hline Total & & 17 & 21 & 14 & 52 & \\
\hline
\end{tabular}

NA, not applicable

Table 8: Distribution of study participants according to their plan to obtain a postgraduate degree locally or abroad

\begin{tabular}{|c|c|c|c|c|c|c|}
\hline & & Year 5 & Year 6 & Intern & Total & Kruskal-Wallis H \\
\hline \multirow{2}{*}{$\begin{array}{l}\text { Are you planning to obtain a } \\
\text { postgraduate degree locally or abroad? }\end{array}$} & Abroad & 14 & 15 & 10 & 39 & 0.03 \\
\hline & Locally & 3 & 6 & 4 & 13 & 0.09 \\
\hline Chi-square $p$ value & & 0.03 & 0.03 & 0.03 & & \\
\hline Total & & 17 & 21 & 14 & 52 & \\
\hline
\end{tabular}

shortage of specialists in these areas and negative experiences in their undergraduate and internship years. Moreover, students are likely to show a change in career preference as they move through their years of undergraduate training into the clinical years. The data generated by this study can be used to improve the quality of the graduate programs available in Saudi Arabia. More focus is needed on mentorship and providing guidance and encouragement to undergraduate dental students in terms of selecting the most appropriate future specialty. A follow-up study is needed to determine if the findings of the present study translate into reality, to improve students' experience and exposure to all dental specialties during their clinical years, and to identify ways of encouraging undergraduates to plan careers in specialty areas that are presently understaffed in the Saudi population.

\section{Author Contributions}

I am the only author of this manuscript and I have the rights to make necessary changes as per the request of the journal, do the rest of the correspondence, and will act as the guarantor for the manuscript. 
Table 9: Distribution of study participants according to why they would consider completing their postgraduate education abroad

\begin{tabular}{|c|c|c|c|c|c|}
\hline $\begin{array}{l}\text { Why would you } \\
\text { complete your } \\
\text { postgraduate educa- } \\
\text { tion abroad? }\end{array}$ & & Year 5 & Year 6 & Dental intern & Total \\
\hline \multirow{23}{*}{$\begin{array}{l}\text { Why would you } \\
\text { complete your } \\
\text { postgraduate educa- } \\
\text { tion abroad? }\end{array}$} & \multirow[b]{2}{*}{ Better learning opportunity } & 3 & 6 & 4 & 13 \\
\hline & & 2 & 1 & 0 & 3 \\
\hline & Better learning opportunity, better research experience & 2 & 1 & 2 & 5 \\
\hline & Better learning opportunity, experiencing another culture & 0 & 1 & 0 & 1 \\
\hline & $\begin{array}{l}\text { Better learning opportunity, experiencing another culture, } \\
\text { better research experience }\end{array}$ & 0 & 1 & 0 & 1 \\
\hline & $\begin{array}{l}\text { Better learning opportunity, experiencing another culture, } \\
\text { future instrument requirements }\end{array}$ & 0 & 0 & 1 & 1 \\
\hline & $\begin{array}{l}\text { Better learning opportunity, experiencing another culture, } \\
\text { future instrument requirements, better research experience }\end{array}$ & 1 & 0 & 0 & 1 \\
\hline & Better learning opportunity, new specialty & 1 & 0 & 0 & 1 \\
\hline & $\begin{array}{l}\text { Better learning opportunity, new specialty, better research } \\
\text { experience }\end{array}$ & 2 & 0 & 0 & 2 \\
\hline & $\begin{array}{l}\text { Better learning opportunity, newly established local program, } \\
\text { new specialty, experiencing another culture }\end{array}$ & 0 & 2 & 0 & 2 \\
\hline & $\begin{array}{l}\text { Better learning opportunity, newly established local program } \\
\text { specialty, experiencing another culture, better research } \\
\text { experience }\end{array}$ & 0 & 4 & 0 & 4 \\
\hline & $\begin{array}{l}\text { Better learning opportunity, poor training opportunity in local } \\
\text { program, new specialty, specialty not currently available locally, } \\
\text { future instrument requirements }\end{array}$ & 0 & 1 & 0 & 1 \\
\hline & $\begin{array}{l}\text { Better learning opportunity, poor training opportunity in local } \\
\text { program, new specialty, specialty not currently available locally, } \\
\text { future instrument requirements, better research experience }\end{array}$ & 0 & 1 & 0 & 1 \\
\hline & $\begin{array}{l}\text { Better learning opportunity, practising in a different healthcare } \\
\text { system }\end{array}$ & 0 & 1 & 0 & 1 \\
\hline & $\begin{array}{l}\text { Better learning opportunity, practising in a different healthcare } \\
\text { system, better research experience }\end{array}$ & 1 & 0 & 0 & 1 \\
\hline & $\begin{array}{l}\text { Better learning opportunity, practising in a different healthcare } \\
\text { system, newly established local program, prestige of interna- } \\
\text { tional qualification, experiencing another culture, future instru- } \\
\text { ment requirements }\end{array}$ & 0 & 0 & 1 & 1 \\
\hline & $\begin{array}{l}\text { Better learning opportunity, practising in a different healthcare } \\
\text { system, newly established local program, prestige of interna- } \\
\text { tional qualification, experiencing another culture, future instru- } \\
\text { ment requirements, better research experiences }\end{array}$ & 0 & 0 & 1 & 1 \\
\hline & $\begin{array}{l}\text { Better learning opportunity, practising in a different healthcare } \\
\text { system, poor training opportunity in local program, experienc- } \\
\text { ing another culture, future instrument requirements }\end{array}$ & 1 & 0 & 0 & 1 \\
\hline & $\begin{array}{l}\text { Better learning opportunity, practising in a different healthcare } \\
\text { system, poor training opportunity in local program, experienc- } \\
\text { ing another culture, future instrument, better research experi- } \\
\text { ences, future instrument requirements }\end{array}$ & 1 & 0 & 0 & 1 \\
\hline & $\begin{array}{l}\text { Better learning opportunity, practising in a different healthcare } \\
\text { system, prestige of international qualification, experiencing } \\
\text { another culture }\end{array}$ & 0 & 1 & 0 & 1 \\
\hline & $\begin{array}{l}\text { Better learning opportunity, practising in a different healthcare } \\
\text { system, prestige of international qualification, experiencing } \\
\text { another culture, better research experiences }\end{array}$ & 0 & 1 & 0 & 1 \\
\hline & $\begin{array}{l}\text { Better learning opportunity, practising in a different healthcare } \\
\text { system, prestige of international qualification, experiencing } \\
\text { another culture, future instrument requirements }\end{array}$ & 1 & 0 & 0 & 1 \\
\hline & $\begin{array}{l}\text { Better learning opportunity, practising in a different health } \\
\text { system, prestige of international qualification, experiencing } \\
\text { another culture, future instrument requirements, better research } \\
\text { experiences }\end{array}$ & 0 & 0 & 1 & 1 \\
\hline
\end{tabular}


Contd...

\begin{tabular}{|c|c|c|c|c|c|}
\hline & & Year 5 & Year 6 & Dental intern & Tota \\
\hline & $\begin{array}{l}\text { Better learning opportunity, prestige of international qualifica- } \\
\text { tion, better research experiences }\end{array}$ & 1 & 0 & 0 & 1 \\
\hline & $\begin{array}{l}\text { practising in a different healthcare system, better research } \\
\text { experiences }\end{array}$ & 0 & 0 & 2 & 2 \\
\hline & $\begin{array}{l}\text { practising in a different healthcare system, specialty not cur- } \\
\text { rently available locally, prestige of international qualification, } \\
\text { experiencing another culture }\end{array}$ & 0 & 0 & 1 & 1 \\
\hline & $\begin{array}{l}\text { practising in a different healthcare system, specialty not cur- } \\
\text { rently available locally, prestige of international qualification, } \\
\text { experiencing another culture, better research experiences }\end{array}$ & 0 & 0 & 1 & 1 \\
\hline & $\begin{array}{l}\text { Prestige of international qualification, better research experi- } \\
\text { ences }\end{array}$ & 1 & 0 & 0 & 1 \\
\hline Total & & 17 & 21 & 14 & 52 \\
\hline
\end{tabular}

\section{ACKNOWLedgment}

The author is grateful to Dr Sakeenabi Basha for her kind advice.

\section{References}

1. Ministry of Higher Education [Internet] [cited 2020 January 27] file:///D:/researchcarrechoice/Dalil-Al-Takhassosat.pdf.

2. Puryer J, Selby J, Layton J, et al. The association between postgraduate studies, gender and qualifying dental school for graduates qualifying from UK dental schools between 2000 and 2009. Dent J 2017;5(1):11. DOI: 10.3390/dj5010011.

3. Saudi Health Commission [Internet] [cited 2020 January 27] https:// www.scfhs.org.sa/MESPS/TrainingProgs/TrainingProgsStatement/ Pages/index.aspx.

4. Halawany HS, Binassfour AS, AlHassan WK, et al. Dental specialty, career preferences and their influencing factors among final year dental students in Saudi Arabia. Saudi Dent J 2017;29(1):15-23. DOI: 10.1016/j.sdentj.2016.12.001.

5. Mahoney R, Katona C, Mcparland M, etal. Shortage specialties: changes in career intentions from medical student to newly qualified doctor. Med Teach 2004;26(7):650-654. DOI: 10.1080/01421590400019591.

6. Lambert TW, Goldacre MJ. Views of doctors in training on the importance and availability of career advice in UK medicine. Med Educ 2007;41(5):460-466. DOI: 10.1111/j.1365-2929.2006. 02675.x.

7. Ashour A, Ashour A, Asiri M, et al. Career choices of final year medical students and interns at King Abdulaziz University: where does orthopaedics stand? J Health Specialt 2018;6(1):23. DOI: 10.4103/jhs. JHS_49_17.

8. Folayan MO, Sofola OO, Khami MR, et al. Study motives, career choices and interest in paediatric dentistry among final year dental students in Nigeria. BMC Med Educ 2014;14(1):130. DOI: 10.1186/1472-6920-14-130.

9. Halawany HS. Career motivations, perceptions of the future of dentistry and preferred dental specialties among Saudi dental students. Open Dent J 2014;8(1):129. DOI: 10.2174/1874210601408010129.

10. Stewart FMJ, Drummond JR, Carson L, et al. The future of the profession - a survey of dental school applicants. Br Dent J 2004;197(9):569-573. DOI: 10.1038/sj.bdj.4811810.

11. Orenuga OO, da Costa OO. Characteristics and study motivation of clinical dental students in nigerian universities. J Dent Educ 2006;70(9):996-1003. DOI: 10.1002/j.0022-0337.2006.70.9. tb04171.x.

12. Hallissey J, Hannigan A, Ray N. Reasons for choosing dentistry as a career-a survey of dental students attending a dental school in Ireland during 1998-99. Eur J Dent Educ 2000;4(2):77-81. DOI: 10.1034/j.1600-0579.2000.040205.x.

13. Jover M, Doudoux D, Deveaux E. Representations of the dental surgery profession and the motivations given by second-year french students for applying for dental surgery. Eur J Dent Educ 2006;10(1):2-9. DOI: 10.1111/j.1600-0579.2006.00386.x.
14. Stewart FMJ, Drummond JR, Carson L, et al. A survey of dental school applicants' career intentions and the balance with family life. Br Dent J 2005;198(11):713-717. DOI: 10.1038/sj.bdj.4812391.

15. Vigild M, Schwarz E. Characteristics and study motivation of danish dental students in a longitudinal perspective. Eur J Dent Educ 2001;5(3):127-133. DOI: 10.1034/j.1600-0579.2001.050306.x.

16. Crossley ML, Mubarik A. A comparative investigation of dental and medical student's motivation towards career choice. Br Dent J 2002;193(8):471-473. DOI: 10.1038/sj.bdj.4801599.

17. Dal MP, Quain EE, O'Neil M, et al. Addressing the health workforce crisis: towards a common approach. World Hosp Health Ser 2006;42(4):27-29.

18. Bernabe E, Icaza JL, Delgado-Angulo EK. Reasons for choosing dentistry as a career: a study involving male and female firstyear students in Peru. Eur J Dent Educ 2006;10(4):236-241. DOI: 10.1111/j.1600-0579.2006.00422.x.

19. Khami MR, Murtomaa $H$, Jafarian M, et al. Study motives and career choices of Iranian dental students. Med Princ Pract 2008;17(3): 221-226. DOI: 10.1159/000117796.

20. Scarbecz M, Ross JA. Gender differences in first-year dental students' motivation to attend dental school. J Dent Educ 2002;66(8):952-961. DOI: 10.1002/j.0022-0337.2002.66.8.tb03564.x.

21. Winter PA, Butters JM. An investigation of dental student practice preferences. J Dent Educ 1998;62(8):565-572. DOI: 10.1002/j.00220337.1998.62.8.tb03215.x.

22. Cleland JA, Johnston PW, Anthony M, et al. A survey of factors influencing career preference in new-entrant and exiting medical students from four UK medical schools. BMC Med Educ 2014;14(1):151. DOI: 10.1186/1472-6920-14-151.

23. Sam G, Alghmlas AS, Alrashed Ml, et al. Working environment and specialty of choice chosen by the dental students at Prince Sattam Bin Abdulaziz university, Saudi Arabia: a cross-sectional study. Journal of International Society of Preventive \& Community Dentistry 2016;6(1):1.

24. Kabil NS, Allam GG, Abd El-Geleel OM. Motivational reasons for choosing dentistry as a professional career \& factors affecting specialty choice among final year dental students. Fut Dent $J$ 2018;4(2):308-313. DOI: 10.1016/j.fdj.2018.04.002.

25. Al Agili DE. A systematic review of population-based dental caries studies among children in Saudi Arabia. Saudi Dent J 2013;25(1):3-11. DOI: 10.1016/j.sdentj.2012.10.002.

26. Abdulghani HM, Al-Shaikh G, Alhujayri AK, et al. What determines the selection of undergraduate medical students to the specialty of their future careers? Med Teach 2013;35(1):25-30. DOI: 10.3109/0142159X.2013.765548.

27. Al-Dlaigan $\mathrm{YH}, \mathrm{Al}$-Sadhan $\mathrm{R}, \mathrm{Al}-\mathrm{Ghamdi} \mathrm{M}$, et al. Postgraduate specialties interest, career choices and qualifications earned by male dentists graduated from King Saud University. Saudi Dent J 2011;23(2):81-86. DOI: 10.1016/j.sdentj.2010.11.004. 